International Research Journal of Management, IT \& Social Sciences
Available online at https://sloap.org/journals/index.php/irjmis/
Vol. 6 No. 2, March 2019, pages: 12 21
ISSN: 2395-7492
https://doi.org/10.21744/irjmis.v6n2.601

\title{
The Effect of Profitability in Income Smoothing Practice with Good Corporate Governance and Dividend of Payout Ratio as a Moderation Variable
}

Ni Made Yeni Witaris Asmita Yanti ${ }^{a}$ A.A.N.B. Dwirandra ${ }^{b}$

Article history:

Received: 9 September 2018

Accepted: 31 January 2019

Published: 16 March 2019

\section{Keywords:}

dividend;

good corporate;

governance;

payout ratio;

profitability;

\begin{abstract}
One of the factors that influence income smoothing is profitability. Profitability is the ability of a company to earn profits or profits in a certain period and as a measure of the management effectiveness of a company. The variables of good corporate governance and dividend payout ratio are thought to play a role in moderating the effect of profitability on the probability of the occurrence of income smoothing practices. The sample selection method in this study used a purposive sampling method with the criteria of all companies listed on the Stock Exchange which were included in the CGPI ranking from 2012-2016 and companies that distributed dividends from 2012-2016. The sample in this study were 7 companies with 5 years of observation. The variable income smoothing practice is measured using the Eckel index. The variable profitability is measured using the ROA (Return On Asset) ratio. Variables of good corporate governance are measured using the CGPI score. Dividend payout ratio variables are measured using the dividend per share formula divided by earnings per share. The analysis technique used is the logistical binary regression and Moderated Regression Analysis (MRA). The results of this study indicate that profitability has a positive effect on the probability of the occurrence of income smoothing practices. Good corporate governance is not able to weaken the positive influence of profitability on the probability of income smoothing practices. Dividend Payout Ratio is not able to strengthen the positive influence of profitability on the probability of the occurrence of income smoothing practices.
\end{abstract}

2395-7492@ Copyright 2019. The Author. This is an open-access article under the CC BY-SA license (https://creativecommons.org/licenses/by-sa/4.0/) All rights reserved.

\section{Author correspondence:}

Ni Made Yeni Witaris Asmita Yanti,

Faculty Economic and Business of Udayana University, Bali, Indonesia.

Email address: yeniwitaris.989@gmail.com

\footnotetext{
a Faculty Economic and Business of Udayana University, Bali, Indonesia

${ }^{\mathrm{b}}$ Faculty Economic and Business of Udayana University, Bali, Indonesia
} 


\section{Introduction}

Factors that influence a company's income smoothing practices are very diverse. One of the dominant factors that influence income smoothing is profitability. Profitability is the ability of a company to earn profits or profits in a given period and as a measure of the level of management effectiveness of a company (Kasmir, 2014). Profitability ratio is one of the factors that can attract investors to invest. By looking at these opportunities, management will try to increase the company's profitability for each period.

Research conducted by Jamaluddin \& Amanah (2015), found that profitability measured using return on assets has a positive effect on income smoothing. This proves that companies that have a higher return on asset ratio have a greater probability of doing income smoothing compared to lower companies because management knows the company's ability to obtain profits in the future so as to facilitate delaying or accelerating profits.

Research conducted by Kusumaningrostati \& Mutasowifin (2014), also found that return on assets has a positive effect on income smoothing. The study of Rasinih \& Munandar (2016) and Widana \& Yasa (2013), found that profitability had a positive effect on income smoothing practices. This shows that companies with higher profitability will tend to practice income smoothing. This might be because companies that have reported high profits so far will try so that the profits reported in the financial statements in the following years will not experience a drastic decline which will give a negative impression to the shareholders. Research conducted by Handayani (2016), also found results that in pharmaceutical industry companies, profitability had a significant positive effect on income smoothing actions.

The results of different studies conducted by Herlina \& Damayanti (2016), found that profitability had a negative effect on income smoothing practices in companies listed on the Indonesia Stock Exchange which were included in the CGPI ranking in 2010-2014. Research conducted by Trisnawati et al., (2017), also found that profitability had a negative effect on income smoothing practices in companies listed in the LQ45 Index in 2011-2016.

The results of research conducted by Puspitasari \& Putra (2018), found that profitability did not have a significant effect on income smoothing. These results explain that company management minimizes not doing income smoothing because it will endanger the credibility of the company. Research conducted by Yulfita (2014), also found that profitability did not have a significant effect on income smoothing. This result is caused by the differences in income smoothing patterns in two directions. This means that companies do income smoothing by increasing and reducing profits.

Based on the research findings, the effect of profitability on income smoothing practices was found to be varied/inconsistent or controversial which was allegedly due to other factors that influenced the relationship between independent variables and dependent variables. Govindarajan (1986), states that the possibility of the absence of unity of research results depends on certain factors or better known as contingency factors. Murray (1990), explains that in order to reconcile conflicting results a contingency approach is needed to identify other variables that act as moderators or mediators in the research model. Conceptually and the results of empirical research, there are several variables that are thought to play a role in moderating the effect of profitability on the probability of the occurrence of income smoothing practices, one of which is good corporate governance and dividend payout ratio. Research by Herlina \& Damayanthi (2016), which found that profitability had a negative effect on income smoothing suggested that research is conducted on the role of corporate governance in moderating the effect of profitability on income smoothing.

Corporate governance is corporate governance that explains the relationship between shareholders (principals) and company managers (agents) in determining the direction of company performance (Annisa \& Kurniasih, 2012). Corporate governance is expected to be able to strive for a balance between various interests that can provide benefits to the company as a whole. The implementation of corporate governance is also useful to reduce agency costs, namely the costs borne by shareholders due to delegation of authority to management, reducing the cost of capital as a result of the company's management in a healthy manner and responsible for, and increasing the value of the company's shares, as well as creating stakeholder support for the company (license to operate).

The Forum for Corporate Governance in Indonesia (FCGI, 2011), defines GCG as a set of rules that establish relationships between shareholders, administrators, creditors, governments, employees and other internal and external stakeholders in relation to their rights and obligations. GCG is a mechanism that is able to provide company rules and control to create added value (Herlina \& Damayanti, 2016).

A company that adheres to GCG will certainly prioritize transparency in financial reporting from managers to shareholders and to the public (Dwirandra et al., 2017). Transparency can be seen in financial reports that are very detailed in the notes so that the public can find out the sources of funds and expenses made by the company. Transparency will prove whether or not opportunistic behavior of management occurs, proving that the relevant corporate governance is good or not. GCG implementation can be measured through the Corporate Governance

Yanti, N. M. Y. W. A., \& Dwirandra, A. (2019). The effect of profitability in income smoothing practice with good corporate governance and dividend of payout ratio as a moderation variable. International Research Journal of Management, IT and Social Sciences, 6(2), 12-21. https://doi.org/10.21744/irjmis.v6n2.601 
Prediction Index (CGPI). CGPI is a research program and ranking of the application of good corporate governance in Indonesia to public companies organized by the Indonesian Institute of Corporate Governance (IlGina \& Damayanti, 2016).

Companies that enter corporate governance perception index have a smaller tendency towards income smoothing practices because the company has implemented good corporate management and good relations between shareholders and managers so that it is expected to minimize fraud in any form (Dwirandra \& Suryanawa, 2018).

The reason this study uses companies that are ranked as CGPI is that CGPI research is self-assessment so it is voluntary to register to take part in the research and find out whether all companies included in the CGPI ranking do not do income smoothing or there are still income smoothing practices because those included in the CGPI rankings have been seen so well by shareholders and the wider community.

The dividend payout ratio is a percentage of dividends to the value of net income owned by the company. Dividend policy determines whether company profits will be shared with shareholders in the form of dividends or held as investment financing in the future. The dividend to be paid in amount is determined by the profits generated by the company (Budiasih, 2009). Stable earnings flow can support a higher dividend rate than a variety of profit streams (Riahi \& Belkaoui, 2007b). This is what spurs management to smooth profits (Widana \& Yasa, 2013).

\section{Literature Review and Hypothesis}

Based on The Bonus Plan Hypothesis, for companies that have a bonus plan, company managers will prefer accounting methods that can shift profits from the future to the present so that they can increase profits this time. This can mean that companies with low profitability encourage managers to practice income smoothing so that the company's profits will increase, so they get a higher bonus (Yulfita, 2014).

Wijoyo (2014), found that profitability had a positive effect on income smoothing practices. Companies with higher profitability will tend to practice income smoothing. This might be because companies that have reported high profits will try to make the profits reported in the financial statements in the following years do not experience a drastic decline which will give a negative impression to the shareholders so that the company will tend to practice income smoothing.

This statement is supported by the research of Widana \& Yasa (2013), found that profitability has a positive effect on income smoothing practices. The same thing was also expressed by the research of Rasinih \& Munandar (2016), who found that profitability had a positive effect on income smoothing practices.

Based on the explanation, the hypothesis is formulated as follows:

H1: Profitability has a positive effect on the probability of the occurrence of income smoothing practices.

Based on the Agency Theory, the principal employs an agent to provide a service and then delegates decisionmaking authority to the agent. With the authority that is owned, the manager has the possibility to not act the best for the interests of the owner because of differences in interests.

Management's vested interest results in the need for a check and balance process to reduce the possibility of misuse of power by management. The mechanism that can be done to overcome this problem is by implementing good corporate governance. Good Corporate Governance (GCG) is a form of good corporate management, which includes a form of protection against the interests of shareholders (public) as company owners and creditors as external funders. A good corporate governance system will provide effective protection to shareholders and creditors to regain investment in a reasonable, appropriate and efficient manner, and ensure that management acts as well as it can for the company's interests (The Indonesian Institute for Corporate Governance, 2004).

Good Corporate Governance has five basic principles, namely transparency, accountability, responsibility, independence, and fairness. The application of GCG principles is expected to narrow the scope of management to carry out actions on earnings management, such as income smoothing (Rofika \& Zirman, 2012).

Research conducted by Apriyani et al., (2015), found that good corporate governance variables proxied by audit committees and institutional ownership influence income smoothing. While the independent board of commissioners and managerial ownership have no effect on income smoothing.

Research conducted by Manukaji (2018), also found that corporate governance has a significant effect on income smoothing. Research conducted by Widhyawan \& Dharmadiaksa (2015), found that corporate governance variables had a negative effect on income smoothing.

From the results of these studies, good corporate governance is thought to have the opportunity to moderate the effect of profitability on income smoothing practices. The research conducted by Herlina \& Damayanti (2016), found that Good corporate governance strengthened the negative influence of profitability on income smoothing practices. Based on these descriptions the research hypotheses were formulated as follows: 
H2: Good corporate governance weakens the positive influence of profitability on the probability of the occurrence of income smoothing practices.

The dividend payout ratio is the ratio of dividend payments where dividend per share is divided by earnings per share. The amount of the dividend payment is determined from the profits obtained. A stable profit stream can support higher levels of dividends (Riahi \& Belkaoui, 2007b). If there are fluctuations in profits, companies that apply a high dividend payout ratio policy are more likely to take income smoothing actions.

The results of research conducted by Gayatri \& Wirakusuma (2013), found that the dividend payout ratio variable had a positive effect on the opportunities for income smoothing practices. The results of research conducted by Budiasih (2009), also found that the dividend payout ratio had a significant positive effect. From the results of the study dividend payout ratio is thought to have the opportunity to moderate the effect of profitability on income smoothing practices.

Based on the description, the research hypothesis was formulated as follows:

H3: Dividend payout ratio strengthens the positive effect of profitability on the probability of income smoothing practices.

\section{Materials and Methods}

This research was conducted on all companies listed on the Indonesia Stock Exchange (IDX) which entered the CGPI ranking in 2012-2016 and provided annual report data by accessing and downloading the official Indonesia Stock Exchange website through the website www.idx.co.id. IDX is used as the location of the study because the listed companies will deliver information about the activities of their company. This study uses all companies listed on the Indonesia Stock Exchange and entered the CGPI ranking for the period 2012-2016. The population in this study are all companies listed on the Indonesia Stock Exchange for the period 2012-2016.

The method of data collection in this study is a non-participant observation method that is researchers not involved and only as independent observers, researchers read, observe, record, analyze and then make conclusions (Sugiyono, 2014). Data were obtained from www.idx.co.id, the website of each company, and contacted CGPI to obtain data on all participating companies of the Corporate Governance Perception Index (CGPI) in 2012-2016.

The data analysis used in this study is logistic binary regression. The use of binary logistic regression is based on the dependent variable.

\section{Results and Discussions}

A logistic regression model can be established by looking at the value of parameter estimates in the variable in the equation. The formed regression model has two equations. The first equation to see the effect of profitability on income smoothing practices. The results of the first test model can be seen in Table 1.

Table 1

Regression testing result

\begin{tabular}{ccc}
\hline Model & Koefisien Regresi & Signifikansi \\
\hline X & 56,192 & 0,028 \\
Konstanta & $-2,738$ & 0,003 \\
\hline
\end{tabular}

Sumber: Primary Data, 2018

The regression model formed based on the value of parameter estimation in the variable in the equation is as follows:

Ln $\frac{P L}{1-P L}=-2,738+56,192 X_{1}$

Yanti, N. M. Y. W. A., \& Dwirandra, A. (2019). The effect of profitability in income smoothing practice with good corporate governance and dividend of payout ratio as a moderation variable. International Research Journal of Management, IT and Social Sciences, 6(2), 12-21. https://doi.org/10.21744/irjmis.v6n2.601 
The second equation model is formed by incorporating the interaction of profitability and good corporate governance variables and the interaction of profitability with the dividend payout ratio with the regression results presented in Table 2.

Table 2

Regression testing result

\begin{tabular}{|c|c|c|}
\hline Model & Koefisien Regresi & Signifikansi \\
\hline $\mathrm{X}_{1}$ & $-1857,739$ & 0,224 \\
\hline $\mathrm{M}_{1}$ & $-0,846$ & 0,139 \\
\hline $\mathrm{M}_{2}$ & $-5,077$ & 0,800 \\
\hline $\mathrm{X}_{1} \mathrm{M}_{1}$ & 22,828 & 0,191 \\
\hline $\mathrm{X}_{1} \mathrm{M}_{2}$ & 103,878 & 0,810 \\
\hline Konstanta & 69,621 & 0,162 \\
\hline
\end{tabular}

Sumber: Primary Data, 2018

The regression model formed based on the value of parameter estimation in the variable in the equation is as follows:

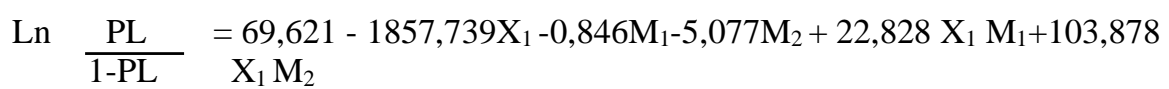

\subsection{Profitability on Probability of the Income Smoothing Practice}

The profitability variable regression coefficient is 56,192 with a significance value of 0,028 which is less than $\alpha=$ 0,05 which means $\mathrm{H} 1$ is accepted, which means that profitability has a positive effect on the probability of income smoothing practices. This shows that the higher the profitability, the better the chance of income smoothing.

These results support the bonus plan hypothesis which states that in companies that have a bonus plan, company managers will prefer accounting methods that can shift profits from the future to the present so they can increase profits in this period. Companies with low profitability encourage managers to practice income smoothing so that the resulting profits increase, so managers get a higher bonus.

This result is in line with the research conducted by Wijoyo (2014); Widana \&Yasa (2013); Budiasih (2009) and Rasinih \& Munandar (2016), who found that profitability had a positive effect on income smoothing practices. Companies with high profitability will tend to practice income smoothing because companies that have reported high profits so far will try to make the profits reported in the following year do not experience a drastic decline which gives a negative impression to the shareholders.

\subsection{Good Corporate Governance to Moderate on Effect of Profitability on the Probability of the Income Smoothing Practice}

The moderation coefficient of good corporate governance on the effect of profitability on the probability of income smoothing practices is 22.828 with a significance value of 0.191 which is more than $\alpha=0.05$ which means $\mathrm{H} 2$ is rejected, which means that good corporate governance is not able to weaken the positive effect of profitability on the probability of flattening practices profit. These results indicate that the presence of good corporate governance does not affect the probability of the occurrence of income smoothing practices.

This result is contrary to the assumption that the existence of good corporate governance can narrow the scope of management to carry out income smoothing actions (Rofika \& Zirman, 2012). Thus the results of this study are not consistent with the research of Herlina \& Damayanti (2016), who found that good corporate governance strengthens the negative influence of profitability on income smoothing practices. The results of this study are also not consistent with Manukaji's research (2018) which found that corporate governance has a significant effect on income smoothing. However, the results of this study are in line with research conducted by Dewantari \& Badera (2015) and Apriyani, et al., (2015), who found that good corporate governance had no effect on income smoothing practices.

The lack of effect of good corporate governance on the probability of income smoothing is likely to occur because the number of participants participating in the IICG survey is still relatively small, which is around 43 companies each 
year so that it cannot yet represent all existing companies. The sample in this study was also relatively small, 35 observations for 5 years so that they could not represent the existing company.

\subsection{Dividend Payout Ratio to Moderates on the Effect of Profitability on the Probability of Income Smoothing Practice}

The dividend payout ratio moderation coefficient on the effect of profitability on the probability of income smoothing practices is 103,878 with a significance value of 0.810 which is more than $\alpha=0.05$ which means that $\mathrm{H} 3$ is rejected, which means that the dividend payout ratio is not able to strengthen the positive effect of profitability on the probability of flattening practices profit. These results indicate that the existence of a dividend payout ratio does not affect the probability of income smoothing practices.

These results contradict the research conducted by Gayatri \& Wirakusuma (2013) and Budiasih (2009), who found that dividend payout ratios had a positive effect on income smoothing practices. These results are in line with the research conducted by Widana \& Yasa (2013); Widhyawan \& Dharmadiaksa (2015); Trisnawati et al., (2017); Yuliani et al., (2017) and Pratama (2012), who found that dividend payout ratios had no effect on practice income smoothing.

The effect of dividend payout ratio on the probability of income smoothing is likely to occur because the dividend policy is determined from the General Meeting of Shareholders (GMS). Dividends paid certainly vary depending on the profits obtained if the fluctuations in earnings are too high and dividends paid above average allow for the occurrence of income smoothing (Widana \& Yasa, 2013).

\subsection{Coefficient of Determination (Nagelkerke R Square)}

The magnitude of the coefficient of determination in the logistic regression model is indicated by the value of Nagelkerke R Square. Results from Nagelkerke R Square can be seen in Table 3.

Table 3

Nagelkerke R Square

\begin{tabular}{llll}
\hline & -2 Log Likelihood & Cox \& Snell R Square & Nagelkerke R Square \\
\hline 26,681 & 0,427 & 0,583 & \\
\hline
\end{tabular}

Sumber; Primary Data, 2018

Based on Table 3, it can be seen that Nagelkerke R Square is equal to 0.583, which means that the variability of the dependent variable that can be explained by the independent variable is 58.30 percent, while the remaining 41.70 percent is influenced by other variables outside the research model.

\section{Conclusion}

Profitability has a positive effect on the probability of income smoothing practices. Good Corporate Governance is not able to weaken the positive influence of profitability on the probability of income smoothing practices. Dividend Payout Ratio is not able to strengthen the positive influence of profitability on the probability of the occurrence of income smoothing practices. For stakeholders, it is necessary to pay attention to the bonus scheme provided. For companies, it should not be focused on dividend distribution to attract investors, it could be by other methods such as giving bonus shares.

Conflict of interest statement and funding sources

The authors declared that they have no competing interest. The study was financed by personal funding.

Statement of authorship

The authors have a responsibility for the conception and design of the study. The authors have approved the final article.

Acknowledgments

The authors acknowledgment to the editor of IRJMIS for their valuable time, support, and advice.

Yanti, N. M. Y. W. A., \& Dwirandra, A. (2019). The effect of profitability in income smoothing practice with good corporate governance and dividend of payout ratio as a moderation variable. International Research Journal of Management, IT and Social Sciences, 6(2), 12-21. https://doi.org/10.21744/irjmis.v6n2.601 


\section{References}

ADB, J. (2005). World Bank (2005). Sri Lanka 2005 Post-Tsunami Recovery Program: Preliminary Damage and Needs Assessment.

Alexandri, M. B., \& Anjani, W. K. (2014). Income smoothing: impact factors, evidence in Indonesia. International Journal of Small Business and Entrepreneurship Research, 3(1), 21-27.

Annisa, N. A., \& Kurniasih, L. (2012). Pengaruh corporate governance terhadap Tax avoidance. Jurnal Akuntansi \& Auditing, 8(2), 95-189.

Anthony, R. N. dan Vijay Govindarajan. 2005. Management Control System.

Ashari, N., Koh, H. C., Tan, S. L., \& Wong, W. H. (1994). Factors affecting income smoothing among listed companies in Singapore. Accounting and business research, 24(96), 291-301.

Baridwan, Z. (1992). Intermediate Accounting edisi ketujuh. Yogyakarta: BPFE.

Belkaoui, A. R. (2006). Accounting Theory (Buku 1). Edisi Kelima. Jakarta: Salemba Empat.

Bora, M. J., \& Saha, A. (2015). Investigation on the Presence of Income Smoothingâ€"A Study on the Companies Listed in NSE. Global Journal of Management And Business Research.

Brigham, E. F., \& Houston, J. F. (2006). Dasar-dasar manajemen keuangan. Jakarta: Salemba Empat.

Budiasih, I. (2009). Faktor-faktor yang mempengaruhi praktik perataan laba. jurnal ilmiah akuntansi dan bisnis.

Cadbury, A. (1992). Report of the committee on the financial aspects of corporate governance (Vol. 1). Gee.

Corolina, C., \& Juniarti, J. (2006). Analisa faktor-faktor yang berpengaruh terhadap perataan laba (Income smoothing) pada perusahaan-perusahaan go public. Jurnal Akuntansi dan Keuangan, 7(2), 148-162.

Dewantari, N. P. S., \& Badera, I. D. N. (2015). Good Corporate Governance, Ukuran Perusahaan, Dan Financial leverage Sebagai Prediktor Perataan Laba. E-Jurnal Akuntansi, 538-553.

Djaddang, S. (2006). Analisis Hubungan Perataan Laba (Income Smoothing) dengan Ekspektasi Laba Masa Depan Perusahaan Manufaktur yang Terdaftar di Bursa Efek Jakarta. Online), http://research. mercubuana. ac. id/proceeding/Analisis-Hubungan-Perataan-Laba. pdf, diakses, 17.

Donovan, D., \& Amanah, L. (2015). Strategi Pemungutan PBB Sebagai Upaya Meningkatkan Pendapatan Asli Daerah di Kota Mojokerto. Jurnal Ilmu \& Riset Akuntansi, 4(11).

Dwirandra, AANB \& Suryanawa IK. (2018). Idealism and Professional Commitments Mediation the Effect of Work Experience and Training on Ethical Decision Making of Tax Consultan. Research Journal of Finance and Accounting. 9(21), pp. 85.94

Dwirandra, AANB. Badera, IDN. Wirawati, IGP. Widhiyani, NLS. Sujana, IK. (2017). Role of Organizational Commitment, Professional Ethics, Machiavellian Character, and Money Ethic in Moderating the Effect of Professionalism and Auditor Experiences on Materiality Level Consideration. Internationl Journal of Economic Research. 14(10), pp 259-275.

Ebrahimpour, M., ZadehSalteh, H. M., \& Hasan Zadeh, R. B. (2013). The study of the effect of dividend earnings on the quality of earnings with emphasis on the industry type. European Online Journal of Natural and Social Sciences, $2(3(\mathrm{~s}))$, pp-1034.

Fathoni, A. F., \& Taufik, M. (2014). The Influence Profitability, Financial Leverage, and Firm Size on Income Smoothing Empirical Studies on Banking Companies Listed on Stock Exchanges in Indonesia 2009-2012. Jurnal Online Mahasiswa Fakultas Ekonomi Universitas Riau, 1(2).

Fengju, X., Yari Fard, R., Ghassab Maher, L., \& Akhteghan, N. (2013). The relationship between financial leverage and profitability with an emphasis on income smoothing in Iran's capital market. European Online Journal of Natural and Social Sciences, $2(3$ (s)), pp-156.

Fudenberg, D., \& Tirole, J. (1995). A theory of income and dividend smoothing based on incumbency rents. Journal of Political economy, 103(1), 75-93.

Gayatri, I. A., \& Wirakusuma, M. G. (2012). Faktor-faktor yang Mempengaruhi Perataan Laba Perusahaan Manufaktur yang Terdaftar di Bursa Efek Indonesia. Jurnal Akuntansi dan Keuangan, 7(2).

Governance, K. N. K. (2006). Pedoman umum good corporate governance Indonesia.

Gujarati, D. N. (2003). Basic econometrics.: New York: Mcorporate governanceraw-Hill.

Hanafi, M. M., \& Halim, A. (2005). Analisis laporan keuangan, edisi kedua. Yogyakarta: UPP AMP YKPN.

Handayani, S. (2016). Analisis Faktor-Faktor Yang Berpengaruh Terhadap Perataan Laba (Studi Pada Industri Sektor Pertambangan Dan Perusahaan Industri Farmasi Yang Terdaftar Di BEI). JURNAL AKUNTANSI, 1(3), 20Halaman.

Hery, S. E. (2016). Analisis Laporan Keuangan-Integrated And Comprehensive Edition. Gramedia Widiasarana Indonesia. 
Husaini, S. (2016). Determinant Of Income Smoothing At Manufacturing Firms Listed On Indonesia Stock Exchange. International Journal Of Business And Management Invention, 5(9): 01-04.

Imam, G. (2013). Aplikasi Analisis Multivariate dengan Program IBM SPSS 21 Update PLS Regresi. Semarang. Badan Penerbit Universitas Diponegoro. ISBN, 979(015.1).

Juniarta, I. W. A., \& Sujana, I. K. (2015). Pengaruh Financial Leverage Pada Income Smoothing Dengan Good Corporate Governance Sebagai Variabel Pemoderasi. E-Jurnal Akuntansi, 921-939.

Kasmir, S. E. M. M. (2014). Bank dan Lembaga Keuangan Lainnya. Edisi revisi.

Kordlouie, H., \& Sheikhbeglo, A. (2012). Role of Firm Characteristics \& Corporate Governance Mechanism on Type of Earning Smoothing. International Journal of Business and Management, 7(8), 71.

Kusumaningrostati, A., \& Mutasowifin, A. (2016). Analisis pengaruh faktor-faktor terhadap income smoothing dengan gender sebagai variabel moderator pada emiten perbankan. Jurnal Manajemen dan Organisasi, 5(2), 105-121.

Kusumayani, N. L., \& Wirama, D. G. (2016). Good Corporate Governance sebagai Pemoderasi Pengaruh Diversifikasi Operasi dan Diversifikasi Geografis pada Manajemen Laba. E-Jurnal Akuntansi, 2072-2102.

Latrini, M. Y. (2003). Reaksi pasar terhadap tindakan perataan laba (Doctoral dissertation, [Yogyakarta]: Universitas Gadjah Mada).

Lestari, D., \& Satriawan, R. A. (2016). pengaruh corporate governance dan intensitas persediaan terhadap manajemen pajak (Studi Empiris Pada Perusahaan Manufaktur Yang Terdaftar di Bursa Efek Indonesia Tahun 20112013). Jurnal Online Mahasiswa (JOM) Bidang Ilmu Ekonomi, 2(2), 1-15.

Liu, N., \& Espahbodi, R. (2014). Does dividend policy drive earnings smoothing?. Accounting Horizons, 28(3), 501528.

Manukaji, I. J. (2018). Corporate Governance and Income Smoothing in the Nigerian Deposit Money Banks.

Nasir, A., \& Suzanti, A. (2002). Analisis Pengaruh Perataan Laba Terhadap Risiko Pasar Saham dan Return Saham Perusahaan-perusahaan Publik di Bursa Efek Jakarta. KOMPAK. Mei, 4.

Prabayanti, N. L. P. A., \& Yasa, G. W. (2010). perataan laba (income smoothing) dan analisis faktor-faktor yang mempengaruhinya (studi pada perusahaan manufaktur yang terdaftar di bursa. Jurnal Ilmiah Akuntansi dan Bisnis.

Prasetya, H., \& Rahardjo, S. N. (2013). Pengaruh ukuran perusahaan, profitabilitas, financial leverage, klasifikasi KAP dan likuiditas terhadap praktik perataan laba (Doctoral dissertation, Fakultas Ekonomika dan Bisnis).

Pratama, D. F. (2015). Pengaruh profitabilitas, resiko keuangan, nilai perusahaan, struktur kepemilikan dan dividend payout ratio terhadap perataan laba. Journal of Accounting and Investment, 13(1), 35-43.

Puspitasari, N. K. B., \& Putra, I. M. P. D. (2018). Pengaruh Profitabilitas Pada Praktik Perataan Laba dengan Struktur Kepemilikan Sebagai Variabel Pemoderasi. E-Jurnal Akuntansi, 2018(1), 211-239.

Rasinih, R., \& Munandar, A. Pengaruh Financial Leverage dan Profitabilitas Terhadap Income Smoothing Dengan Kualitas Audit Sebagai Pemoderas. Jurnal Ilmiah Akuntansi dan Bisnis.

Reza Pourali, M., \& Dadashi, N. (2014). The relationship between corporate governance mechanisms and profit smoothing. Tehnički vjesnik, 21(3), 617-621.

Saeidi, P. (2012). The relationship between income smoothing and income tax and profitability ratios in iran stock market. Asian Journal of Finance \& Accounting, 4(1), 46.

Samak, N. A., El Said, H. H., \& El Latif, G. A. (2014). corporate governance and income smoothing "case of the egyptian listed companies". International Journal of Management Research and Development, 4(3), 23-42.

Sari, R. P., \& Kristanti, P. (2015). Pengaruh Umur, Ukuran, dan Profitabilitas Perusahaan terhadap Perataan Laba. Jurnal Riset Akuntansi dan Keuangan, 11(1), 77-88.

Scott, W. R. (2003). Financial accounting theory.

Sherlita, E., \& Kurniawan, P. (2013). Analysis of factors affecting income smoothing among listed companies in Indonesia. Jurnal Teknologi, 64(3).

Silviani, F. T. (2014). Faktor-Faktor yang Mempengaruhi Praktik Perataan Laba pada Perusahaan yang Terdaftar Di Bursa Efek Indonesia (BEI) (Doctoral dissertation).

Solomon, M. R. (2010). Consumer behaviour: A European perspective. Pearson education.

Sugiyono, M. P. P. (2007). Pendekatan Kuantitatif. Kualitatif, dan R\&D, Bandung: Alfabeta.

Sugiyono, P. (2015). Metode penelitian kombinasi (mixed methods). Bandung: Alfabeta.

Suprayitno, G. (2005). Internalisasi good corporate governance dalam proses bisnis. Indonesian Institute for Corporate Governance.

Sutrisno. (2002). Studi Manajemen Laba (Earnings Management): Evaluasi Pandangan Profesi Akuntansi. Pembentukan dan Motivasinya. Jurnal Akuntansi Manajemen dan Sistem Informasi STIE, 2(2): 158-179.

Yanti, N. M. Y. W. A., \& Dwirandra, A. (2019). The effect of profitability in income smoothing practice with good corporate governance and dividend of payout ratio as a moderation variable. International Research Journal of Management, IT and Social Sciences, 6(2), 12-21. https://doi.org/10.21744/irjmis.v6n2.601 
Trisnawati, M., Nazar, M. R., \& Yudowati, S. P. (2017). Pengaruh Profitabilitas, Dividend Payout Ratio Dan Financial Leverage Terhadap Income Smoothing. eProceedings of Management, 4(3).

Watts, R. L., \& Zimmerman, J. L. (1986). Positive accounting theory.

Widana, I. N. A. N., Ari, N., \& Yasa, G. W. (2013). Perataan laba serta faktor-faktor yang mempengaruhinya di bursa efek Indonesia. E-Jurnal Akuntansi Universitas Udayana, 3(2), 297-317.

Widhyawan, I. M. I., \& Dharmadiaksa, I. B. (2015). Pengaruh Financial Leverage, Dividend Payout Ratio, Dan Penerapan Corporate Governance Terhadap Praktik Perataan Laba. E-Jurnal Akuntansi, 157-172.

Wijoyo, D. S. (2014). Variabel-Variabel yang Mempengaruhi Praktik Perataan Laba pada Perusahaan Manufaktur yang Publik. Jurnal Bisnis dan Akuntansi, 16(1), 37-45.

Yang, C. Y., Leing Tan, B., \& Ding, X. (2012). Corporate governance and income smoothing in China. Journal of Financial Reporting and Accounting, 10(2), 120-139.

Yulfita, D. (2014). Pengaruh Profitabilitas, Kebijakan Dividen, Dan Pertumbuhan Perusahaan Terhadap Praktik Perataan Laba (Studi Empiris pada Perusahaan Manufaktur yang Terdaftar Di BEI Tahun 2008-2012). Jurnal Akuntansi, 2(2).

Yuliani, N. L., Susanto, B., \& Dwiyanto, R. analisis determinasi praktik perataan laba.

Zarkasyi, W. (2008). Good corporate governance pada badan usaha manufaktur, perbankan, dan jasa keuangan lainnya. Bandung: Alfabeta.

Zarnegar, Z., \& Hamidian, M. (2016). Examining the Relationship between Profitability, Financial Leverage and Income Smoothing at Firms Listed on Tehran Stock Exchange. Iranian Journal of Business and Economics, 3, 8083. 


\section{Biography of Authors}

\begin{tabular}{|l|l||}
\hline & $\begin{array}{l}\text { Ni Made Yeni Witaris Asmita Yanti was born on August 05 } 5^{\text {th }} \text { 1989 in Tejakula. She is } \\
\text { interested in economics, especially accounting. She worked at Warna Jaya Textile in } \\
\text { accounting staff. She graduated her bachelor degree in the Faculty of Economics and } \\
\text { Business, Udayana University, Bali in 2010. She currently is finishing her Master Degree } \\
\text { in accounting at Udayana University in 2019. } \\
\text { Email: yeniwitaris.989@gmail.com }\end{array}$ \\
\hline & $\begin{array}{l}\text { Dr. Drs. A. A. N. B. Dwirandra was born in Denpasar, December 23 }{ }^{\text {th }} \text { 1964. He is a } \\
\text { lecturer on Udayana University, Faculty of Economic and Business, Departement of } \\
\text { Accounting. He graduated his bachelor degree in Airlangga University (Surabaya, } \\
\text { Indonesia), Master Program in Gajah Mada University (Yogyakarta, Indonesia), } \\
\text { Doctoral Program in Brawijaya University, (Malang, Indonesia). } \\
\text { Email: dwirandra2012@gmail.com }\end{array}$ \\
\hline
\end{tabular}

Yanti, N. M. Y. W. A., \& Dwirandra, A. (2019). The effect of profitability in income smoothing practice with good corporate governance and dividend of payout ratio as a moderation variable. International Research Journal of Management, IT and Social Sciences, 6(2), 12-21. https://doi.org/10.21744/irjmis.v6n2.601 